\section{Taikoja ja tenhoa Oxfordissa: raportti Living in a Magical World: Inner Lives -konferenssista ja Spellbound- näyttelystä}

\author{
Lauri Ockenström
}

Oxfordin syyskuu 2018 oli maaginen. Ashmolean Museumissa oli juuri avattu magian ja noitavainojen historiaa esittelevä, laajaa kiinnostusta herättänyt Spellbound: Magic, Ritual, Witchcraft -näyttely, ja St Anne's Collegessa järjestettiin samojen tahojen organisoima, todennäköisesti tämän vuoden merkittävin magian ja esoteeristen alojen tutkijatapaaminen Living in a Magical World: Inner lives, 1300-1900.

Inner lives eli harkitusti hetkessä ja yhdisti huippunimiä

Inner lives -konferenssin teemaksi oli valittu yksilöllinen kokemus henkiolentojen, näkymättömien voimien ja salaisten omi- naisuuksien täyttämässä maailmassa. Esitelmäkutsussa toivottiin puhujien käsittelevän esimerkiksi minuuden ja identiteetin historiaa, subjektiivisuutta ja etenkin tunteiden nivoutumista osaksi yliluonnollista kokemusta. Valinta oli muodinmukainen ja tuoksahti hivenen laskelmoidulta, mutta näkökulman tarpeellisuutta on toisaalta mahdoton kiistää.

Tämän hetken tarpeista juontuvana voidaan pitää sitäkin, että magiaksi, noituudeksi, taikauskoksi ja yliluonnollisiksi uskomuksiksi kutsuttujen ilmiöiden tutkimus haluttiin tuoda samalle keskustelualustalle. Kyseessä on lisääntyvä käytäntö jota voi pitää perusteltuna. Muutamia magian ja noituuden lähtökohtaisia eroja lukuun ottamatta samankaltaiset uskomusjärjestelmät ja maailmankuvat ovat kaikkina aikoina vaikuttaneet magian ja taikauskon eri muotojen taustalla.

Monitieteisiä lähestymiskulmia väistämättä vaativat lähtökohdat asettivat puhujille luonnollisesti myös haasteita, joista selviämiseen palaan myöhemmin. Ainakin osallistujakunnassa järjestäjien toive monialaisuudesta toteutui verrattain hyvin. Aikaikkunansa vuoksi - vuodesta 1300 vuoteen 1900 - Inner lives oli odotetusti historioitsijoiden dominoima konferenssi, mutta paikalla oli myös arkeologeja, kieli- ja kirjallisuustieteilijöitä, taidehistorioitsijoita, etnologeja ja ainakin yksi psykologi.

Oppialojen ohella konferenssi yhdisti myös instituutioita. Mukana oli keskeisiä vaikuttajia kaikista kolmesta magian tai esoteeristen liikkeiden akateemisen tutkimuksen nykyisestä pääorganisaatiosta: Warburg-instituutista, amerikkalaisesta Societas Magica -verkostosta, jonka parissa tutkitaan pääasiassa keskiajan magiaa, ja enimmäkseen moderniin esoteriaan keskittyvästä eurooppalaisesta ESSWE-järjestöstä (European Society for the Study of Western Esotericism). 
Myös osallistujalista oli vakuuttava: magian historian tutkimusparadigman uudistamisen 1980-90-luvuilla käynnistäneet Richard Kieckhefer ja Claire Fanger, klassikkohistorioitsija Ronald Hutton, brittiläisen magian historian uudelleen kirjoittaneet Sophie Page ja Catherine Rider sekä monia muita. Ei ole kovin suurta liioittelua sanoa, että kyseessä oli pitkään aikaan merkittävin konferenssi, joka yhdisti sekä magian että esoteeristen liikkeiden merkittävimmät tutkijat monelta alalta samaan saliin.

\section{Paradigmanmuutoksen jälkikaronkka}

Eri sukupolvien, tutkimussuuntausten ja mannerten kohtaamisessa oli havaittavissa eräänlaista välitilinpäätöksen makua: keskusteluissa arvioitiin myötämielisesti viime vuosikymmeninä tutkimuksessa tapahtunutta edistystä ja luotiin tulevaisuuskatsauksia, joissa tieteiden välisen yhteistyön lisääminen korostui.

Tavallaan esiintyjäkattaus ja konferenssin lähtökohdat alleviivasivatkin 1990-luvulla alkaneen murrosvaiheen päätöstä. Alunpitäen 1800-luvulla ja 1900-luvun alkupuolella magiaa tutkittiin voittopuolisesti antropologian alalla. Taikauskon ja magian nähtiin tällöin johtuvan - kuten nykyäänkin - esimerkiksi kausaalisuhteen fataalista väärinymmärtämisestä. Ne rajattiin kuitenkin "rationaalisen" länsimaisen yhteisön ulkopuolelle kuten keskiaikaan ja luonnonkansojen keskuuteen. Jyrkimmät kannanotot katsoivat taikauskoisen ajattelun olevan mahdollista vain henkisesti sairaille, naisille ja lapsille. Lisäksi magia erotettiin tarkasti tieteestä ja uskonnosta, joiden turmeltuneena vastakohtana sitä pidettiin. Dialektinen vastareaktio tapahtui puolestaan 1960-70-luvuilla, kun renessanssin oppineen magian löytäneet warburgiaanit painottivat erojen sijaan tieteen ja magian samankaltaisuuksia, Keith Thomas taas uskonnon ja taikuuden samankaltaisuutta.

Uuden alun virstanpylväänä voidaan pitää Richard Kieckheferin 1989 julkaisemaa Magic in the Middle Ages -teosta, jossa hän toi vahvasti esiin, ettei magian vertaaminen tieteeseen tai uskontoon ole hedelmällinen lähtökohta tutkimukselle. Tämän pohjalta syntyi ja vakiintui ripeästi uusi tutkimustraditio, jota esimerkiksi Claire Fanger ja Sophie Page seurasivat - muutoksen voi nähdä osana humanististen tieteiden yleistä uudistumista, jonka seurauksena aiemmin häpeällisinä tai arvottomina pidetyt tutkimus- kohteet, kuten taikausko tai seksuaalisuus, kelpasivat paremmin akateemisen tutkimuksen kohteeksi. Magian tutkimuksen uusi paradigma ei toki kiistä taikuuden selviä historiallisia yhtymäkohtia esimerkiksi juuri tieteellisen tai uskonnollisen ajattelun kanssa, mutta ei pidä myöskään tarkkaa kategorisointia tarpeellisena. Toisin sanoen jyrkät dikotomiat on hylätty eikä olennaisena pidetä, edustaako tietty lähde magiaa vai uskontoa tai onko se nykytieteen näkökulmasta "oikeassa", vaan mitä se itsessään kertoo aikakaudestaan ja kulttuuristaan.

Vanhalla tutkimusparadigmalla on ollut kannattajia tälläkin vuosituhannella, mutta pääosin uusi tutkijasukupolvi on omaksunut 1990-luvun uudistajien lähestymistavan. Tätä alleviivaten Inner lives -konferenssin esitelmäkutsussa vahvistettiin, ettei maagisia ja okkultteja uskomuksia typistetä enää taikauskoksi, vaan niiden voi katsoa kuuluneen myös korkeasti koulutettujen, henkisesti terveiden ja monien aikalaistensa arvostamien henkilöiden kuten John Deen maailmankatsomukseen. Sama henki oli aistittavissa keskusteluissa: suuri muutos on onnistuneesti takana, ja on aika kääntää katseet hiljalleen seuraavaan askelmaan. 
Vanhaa tuttua ja monitieteisiä avauksia Inhimillisen kokoinen noin sadan osallistujan konferenssi mahtui yhteen kerrokseen Collegen uudisrakennuksessa. Rinnakkaissessioita oli tavallisesti kaksi, joista toinen keskittyi noituuden tutkimukseen, toinen magiaan. Historiallisesti kyse on toki eri ilmiöistä ja myös tutkimusperinteet ovat kulkeneet erillään sadan vuoden ajan, joten jako oli perusteltu. Toisaalta en voinut välttyä ajatukselta, että myös konferenssirakenteiden tasolla jatkuva eristys ei ainakaan edistää ilmiöiden yhteyksien tutkimusta, joka on vielä pitkälti tekemättä.

Sessioiden anti oli tasaisen laadukasta ja kiinnostavaa. Huttonin ja Michael Baileyn kaltaiset retorisesti kyvykkäät etabloidut puhujat pitivät kuulijat vaivatta otteessaan. Uusia avauksia nähtiin kuitenkin varsin maltillisesti, ja monia esityksiä vaivasikin lievä ennakoitavuus. Hetkittäin sessiot toivat mieleen vanhan festivaalin, jossa hyvät artistit esittävät vanhat hittinsä tyylikkäästi, mutta eivät ainuttakaan uutta kappaletta. Muutamilla puhujilla oli myös lieviä vaikeuksia liittää esitystään luontevasti konferenssin tematiikkaan, ja terminologinen tarkkuus saattoi toisinaan kärsiä vieraalle maaperälle siirryttäessä. Kuten eräs puheenvuoro loppupaneelissa totesi, sisäistä maailmaa käsitellessään perinteinen historioitsija on usein mukavuusalueensa ulkopuolella.

Psykologi Bruce Hoodin esitelmä Natural origins of supernatural thinking edusti sen sijaan poikkitieteellisyyttä parhaimmillaan. Hänen yleisesityksensä tarjosi moderniin psykologiaan pohjautuen selkeät syyt samalla kertaa niin taikauskolle, taikuudelle, valeuutisille kuin populismillekin: inmisaivot tuottavat luontaisesti kategorioita ja olettavat kausaalisuutta, luomme intuitiivisia teorioita, kaipaamme ennakoitavuutta ja kontrollia ja olemme sosiaalisia olentoja, jotka uskovat mielellään vertaisryhmän todistusta. Lisäksi inmiskunnalla on aina ollut yleinen taipumus intuitiivisiin väärinkäsityksiin, joihin Hood listasi mieli-ruumis-dualismin, essentialismin ja sympaattisen magian. Tutkimusten mukaan esimerkiksi alle kouluikäiset lapset uskovat, että tiettyä esinettä esittävän valokuvan kasteleminen vahingoittaa itse esinettä, mistä on lyhyt matka voodoo-nuken käyttöön.

Nämä taipumukset ovat toki olleet tiedossa jo pitkään. Esimerkiksi Aby Warburg ja Ernst Gombrich tunnistivat schlitterlogik-ilmi- ön ${ }^{1}$, mutta ajan hengen mukaisesti se nähtiin lasten, primitiivisten kansojen ja historiallisten aikakausien erheenä. Kun puhujan oman rationaliteetin ylikorostamisesta ja liiallisesta irrationaalisen pelosta on nyttemmin (toivottavasti) päästy eroon, voidaan ehkä helpommin tunnustaa, että jokaisen aivot tuottavat lähes automaattisesti taikauskoa. Tämä tarjoaa tutkimukselle huomattavasti realistisemman ja hedelmällisemmän lähtökohdan kuin aiemmat käsitykset arvoladatuista dikotomioista.

\section{Taiteen perikato?}

Pienellä surumielisyydellä panin merkille kuvataiteen heikentyneen roolin magian tutkimuksessa. Jos Gombrichin ja Erwin Panofskyn suurimman suosion harjalla renessanssitaiteesta ei voinut juuri puhua ilman mainintoja uusplatonilaisesta mystiikasta, melankoliasta ja maagisesta ajattelusta, ja magia yhdistettiin lähes luonnostaan kuvataiteisiin, on nyt tultu ehkä vastakkaiseen aallonpohjaan. Toki muutama varsin mainio esitys käsitteli tai sivusi taiteen historiaa: Diane Heath esitteli Canterburyn katedraalin kryptan kapiteelien tarueläinaiheista romaanista veistoskoristelua ja Liliana Leopardi 
uuden ajan alun muotokuvia, joissa kuvattavat pitävät yllään maagisia kiviä ja suojelevia amuletteja.

Kuvataiteen osuus oli joka tapauksessa hyvin vähäinen alleviivaten sitä tosiseikkaa, että 1990-luvulta alkaen magiaa ovat tutkineet voittopuolisesti historioitsijat, joita visuaalinen puoli ei kiinnosta. Toisaalta on yhtä kiistämätöntä, että kuvataidetta magian ja esoteeristen alojen kontekstissa tutkivia taidehistorioitsijoita on vähän. Osin tämä voi olla seurausta panofskylaisen ikonologian joutumisesta huonoon huutoon 1990-luvulla, osin kenties siitä, ettei opiskelijoilla ole tiivistyvien opintosuunnitelmien maailmassa aikaa tutustua oppialan klassikoihin ja kulttuurikonteksteihin. Warburgilaisen tulkintatradition lopahtaminen on sikäli suuri harmi, että magian historiasta olisi nyt saatavissa huomattavasti enemmän tutkimustietoa kuin 1980-luvulla, mikä tarjoaisi yltäkylläisesti välineitä taiteen ja magian yhteiselon tutkimukselle.

Toisaalta kiinnostus visuaaliseen jäämistöön näyttää vuotaneen taiteen sijaan toiselle alalle. Historiatieteissä ripeästi yleistynyt ja jonkinlaiseksi muoti-ilmiöksi noussut materiaalisen kulttuurin tutkimus näkyi kon- ferenssin ohjelmassa monin tavoin. Esitelmissä tarkasteltiin muun muassa sillankaiteisiin kiinnitettävien lemmenlukkojen kulttuurihistoriaa sekä arabialaista paitaa, johon oli kirjailtu suojelevia maagisia merkkejä. Tutkimusalan (ja monien tutkijoiden) nuoruus heijastui toisinaan tarkasteluspektrin kapeutena, mutta suuntauksella on kiistatonta potentiaalia. Tulevaisuudessa tutkimus hyötyisi merkittävästi, jos materiaalisen kulttuurin tutkijat löytäisivät nykyistä paremmin taidehistorian ja visuaalisen kulttuurin tutkimuksen tietopankit, ja jos taidehistorioitsijat puolestaan tarttuisivat hanakammin taiteen ulkopuoliseen esineistöön.

\section{Yhteenvetojen aika}

Konferenssin loppupaneeli oli tavanomaista särmikkäämpi. Yksimielistä kiitosta keräsi lähinnä pitkä ajallinen tarkasteluväli. Historiatieteissä ja taidehistoriassa on ollut tapana korostaa vaivattomasti dynaamiselta kalskahtavaa muutosta ja sen merkityksen tutkimusta, mutta kentän äänet ovat painottaneet yhä enemmän jatkuvuuden ja suoranaisen stagnaation voimaa. Varsinkin esoteeristen alojen tutkimuksessa longue duréen ulottamisen antiikista ja keskiajalta 1900-luvulle
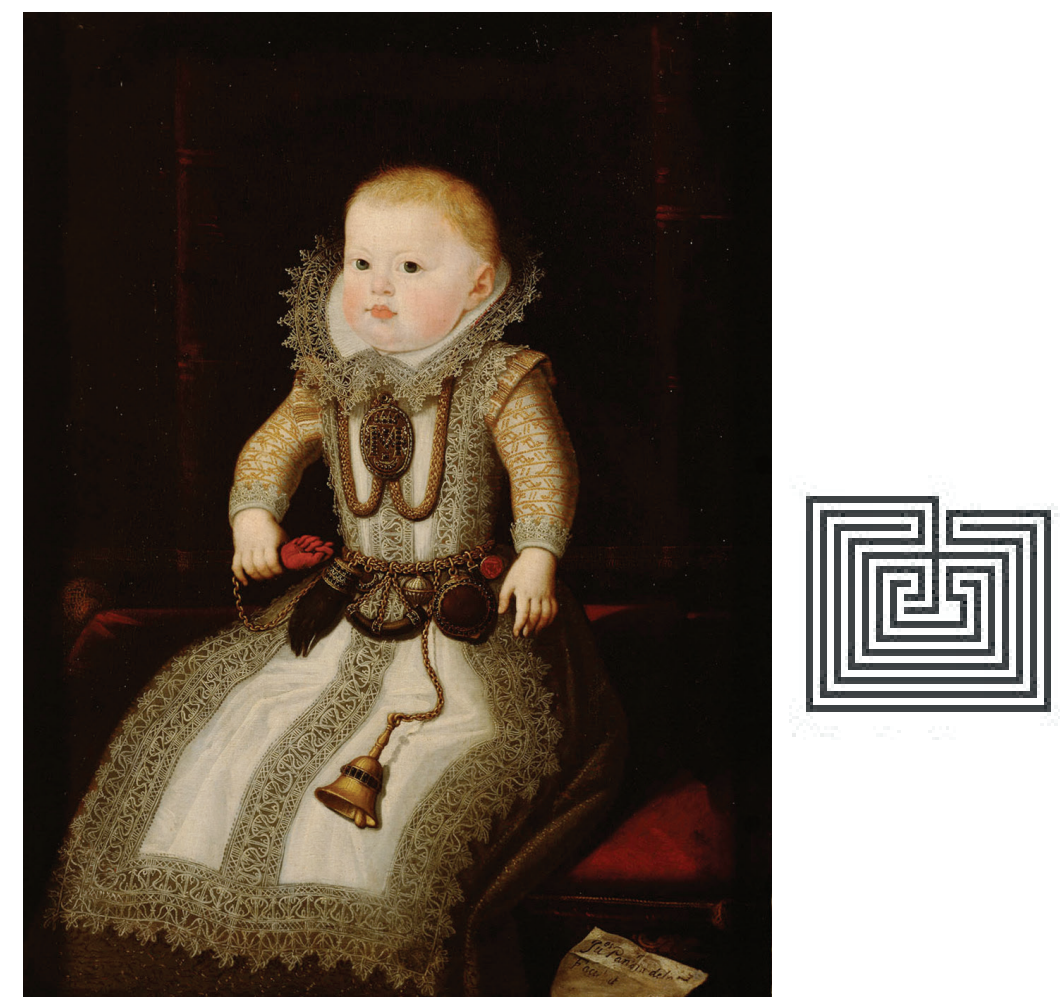

Kuva 1. Juan Pantoja de la Cruz, Espanjan Anna Maria, 1607. Öljyväri kankaalle, 82 × $64 \mathrm{~cm}$ Kunsthistorisches Museum, Wien. Kuva: Kunsthistorisches Museum, Wien, Bilddatenbank / Wikimedia commons.

todettiin olevan hyvin relevantti ratkaisu - mainittakoon yhtenä esimerkkinä, että 1. maailmansodassa ranskalaissotilaat käyttivät suo- 
jelevaa tekstiamulettia, joka pohjautui Kaarle Suuren aikaiseen tekstiin.

Monissa puheenvuoroissa vaadittiin laajempaa tieteenalojen välistä yhteistyötä. Varsinkin arkeologit peräänkuuluttivat uusien yhteyksien avaamista materiaalisen kulttuurin tutkimuksessa. Varsin kiivaasti kaivattiin myös parempi tapoja määritellä mitä tarkoitetaan magialla tai maagisella maailmalla. Tämä kysymys on ollut lopullista ratkaisua vailla vuosikymmenet (pitkälti siksi, ettei nykytutkimus pidä ehdotonta määritelmää välttämättömänä), eikä asiasta syntynyt hedelmällistä jatkodebattia nytkään.

Keskustelun olisikin suonut liikkuvan enemmän siihen suuntaan, mitä konferenssin toisella avaintermillä, sisäisellä elämällä, tarkoitetaan. Erään aiemman keskustelun yhteydessä arabialaisen magian tutkija Liana Saif oli esittänyt kysymyksen, johon ei vielä haettu tyhjentäviä vastauksia: miten maagiset esineet manifestoivat ja tuovat näkyväksi käyttäjänsä sisäistä maailmaa, ja mitä metodeja ja teorioita tämän ilmiön historiallisessa tutkimuksessa olisi sovellettava? Konferenssikokemusten perusteella on helppo todeta, että magian historian - ja maagisen kuvaston - tutkimuksessa tarvitaan tulevaisuudessa parempia välineitä analysoida sisäisen ja ulkoisen itsen käsitteitä sekä materiaalisuuden ja identiteetin suhdetta. Laajempi yhteistyö modernin psykologian kanssa voisi tarjota tähän yhden ratkaisun.

Illat täydensivät tiivistä päiväohjelmaa. Ensimmäisenä iltana vastaanotto järjestettiin kymmenen minuutin patikkamatkan päässä Ashmolean Museumissa, toisena oli vuorossa harvinaisen ylenpalttinen konferenssi-illallinen St. Anne's Collegen kellaritiloissa. Iltoja jatkaneille löytyi viihtyisä pubi heti collegen kulmalta, eikä Tolkienin ja C. S. Lewisin kantapaikka Eagle and Child ollut sekään kuin muutaman kivenheiton päässä. Boheemikaupunginosana tunnettu Jericho levittäytyi taas korttelin päässä lännessä, joten miljööstä ei sopinut valittaa. Enemmistö vieraista yöpyi ja söi aamiaisensa Collegessa, mikä osaltaan edesauttoi pienille tapaamisille ominaisen lämpimän ja intiimin konferenssi-ilmapiirin syntymistä. Inspiroivan ja innostavan atmosfäärin alkulähteistä puhuttaessa ei voi sivuuttaa myöskään itse Oxfordin tenhoa. Lähderepertuaareineen ja muine etuineen siron gotiikan koristama kaupunki on yksi akateemisen maailman ehdottomia helmiä, eikä ihme, että moni konferenssi vieras jäi laillani kaupunkiin pariksi päiväksi kirjastotyöhön.

\section{Spellbound - taikaan tuomittu}

Ashmolean-vierailun yhteydessä konferenssivieraille tarjoutui mahdollisuus tutustua Spellbound: Magic, Ritual, Witchcraft -näyttelyyn loppuillan hiljaisuudessa. Kaksi vuotta sitten Ashmoleanissa oli esillä islamilaisen maailman magiaa esitellyt näyttely, joten kristillisen Euroopan maagisia perinteitä valaiseva Spellbound oli nähtävä sille jatkona. Näyttelyn taustalla hääri muun muassa Sophie Page, yksi tunnetuimmista keskiajan magian nykytutkijoista, joten paljon paremmissa käsissä kuratointi ei olisi voinut olla.

Ashmolean Museum on keräilijä Elias Ashmolen lahjoituksen varaan perustettu museo. Nykyisi Ashmolean on Oxfordin yliopiston museo ja toimii tiiviissä yhteistyössä tutkijayhteisön kanssa, mistä Spellbound-näyttely on hyvä esimerkki. Alkemiasta ja astrologiasta kiinnostuneen Elias Ashmolen alkuperäinen kokoelma oli tyypillinen 1600-luvun kuriositeettikabinettikokoelma, joten museon oma kokoelma sisälsi jo valmiiksi runsaasti maagista esineistöä ja maagisia tekstejä sisältäviä käsikirjoituksia. Museon kolmanteen 
kerrokseen pystytettyä näyttelyä varten esineistöä oli lainattu toki muualtakin kiitettävällä viitseliäisyydellä.

Hitchcockin klassikkoelokuvan nimeä kierrättävä näyttely rakentui kolmesta osasta. Ensimmäinen valaisi kirjallisen jäämistön keinoin oppineen magian perintöä ja maailmanselityksiä, joiden varaan maagiset uskomukset rakentuivat. Toinen osa esitteli kansanuskomusten kirjoa aineellisen jäämistön avulla, kolmas noituuskäsityksiin liittyvää kuvastoa ja esineistöä. Näyttelyesineistön ulottuminen sydänkeskiajalta 1900-luvulle painotti taikauskoisten mallien sinnikästä, opillisten maailmankuvien muutoksille immuunia eloonjäämisviettiä.

Ensimmäinen osio keskittyi käsikirjoituksiin. Esillä oli niin kosmologiaa, astrologiaa kuin alkemiaakin käsitteleviä oppaita ja luonnollisesti magian manuaaleja, joiden rikas kuvitus kertoi teoksia kohtaan tunnetusta arvostuksesta. Kirjallisen evidenssin painoarvoa korostaa oppineeseen magiaan liittyvän aineellisen jäämistön olemattomuus. Esimerkiksi talismaanikuvien valmistamista käsitteleviä manuaaleja tunnetaan kymmenittäin, mutta itse kuvia on säilynyt vain jokunen, nekin uuden ajan puolelta. Aineiston niukkuutta kuvaa hyvin se, että lähes kaikki tunnetut 1500-1600-luvuilta säilyneet talismaanit, maagiset peilit ja kristallipallot mahtuivat vaivatta yhteen pieneen vitriiniin.

Esillä olleet talismaanit edustivat pienille pyöreille metallilaatoille kaiverrettuja, planeetoille omistettuja talismaaneja. Tavanomaisen talismaanin etupuolelle oli kuvattu tietyn planeetan personifikaatio, kääntöpuolelle numeroita sisältävä maaginen ristikko - Jupiter-planeetan neliö toistuu tunnetusti Dürerin Melencolia I -kaiverruksessa. Viiden talismaanin ja muutaman sormuksen ohella esillä oli maaginen peili ja Elisabeth I:n hoviastrologi John Deelle kuulunut kristallipallo, joiden alkuperä on niin ikään jäljitettävissä keskiaikaisiin manuaaleihin. 1500-luvun kristallipallot eivät olleet juuri tavanomaista Fazerin vihreää kuulaa kookkaampia, joten Aku Ankkojen tarjoama käsitys jalkapallon kokoisista ennustusvälineistä on auttamatta väärä.

Kiehtovimman väläyksen tarjosi edelleenkin suhteellisen vähän tutkittua kansankulttuuria käsitellyt osio. Kansanperinteessä käytettyjen esineiden funktio oli useimmiten suojeleva tai ennaltaehkäisevä: ne toivat suojaa noituudelta, kirouksilta, onnettomuuksilta ja sairauksilta. Osa tuotti hyvää onnea, pientä osaa käytettiin taas kirouksiin. Muumioidut pieneläimet, luut, naulalla lävistetyt mollamaijat, piikkien puhkoma ja muodottomaksi mädäntynyt rupikonna, rituaalitarkoituksiin käytetyt kengät ja vaatekappaleet tai pienellä pyhäinjäännöslippaalla ja maagisella kivellä varustettu miekankahva kertoivat kiehtovaa tarinaa siitä miten laajalle materiaalisen kulttuurin joka sopukkaan se, mitä nykyään kutsuisimme maagiseksi ajatteluksi, oli levinnyt.

Noituussektio käsitti etupäässä 1500-1600-lukujen maalaustaidetta ja grafiikkaa sekä noituuden tunnistamiseen tarkoitettua esineistöä.

Jälkimmäiseen kuului esimerkiksi nöyryyskaapu, karkeasta puuvillasta tehty mekko, jonka oli tarkoitus pitää paholainen loitolla ja auttaa noituudesta epäiltyä kuulusteltua antamaan rehellisiä vastauksia. Noitavaaka oli puolestaan suurikokoinen tasapainovaaka, jonka punnuksiksi asetettiin noituudesta epäilty sekä muutama suuri raamattu - tarkoitus oli, että pyhä kirjoitus osoittautuisi noitaa painavammaksi. 
Kuva-aineiston syntyaika ja aiheet heijastivat kohdettaan. Sinnikkäistä keskiaikaan liitetyistä stereotypioista huolimatta noituus on uuden ajan ilmiö, sillä nykyinen noituus-käsitys muotoutui 1400-luvulla, ja suurimmat noitavainot (joiden laajuutta vanha historiankirjoitus huomattavasti liioitteli) sijoittuvat 1500-1600-luvuille. Aineisto koostui enimmäkseen noituuden vastaisesta propagandasta, mikä peilasi varsin tarkoin sitä mistä ilmiössä oli kyse: kirjallisuuden narratiivista ja juridisesta rikosnimikkeestä. Esillä oli esimerkiksi Matthäus Merian vanhemmman, Lucantio degli Ubertin ja Jacob Binckin varsin särmikästä ja noituuspelkoja karnevalistisin keinoin kuvaavaa grafiikkaa. Näyttelyn tunnetuin yksittäinen teos liene Salvator Rosan National Galleryn perusnäyttelystä lainattu Witches and their Incantations -maalaus, joka on yksi esimerkki Rosan monista noituus-aiheisista töistä.

1500-luvun teoksissa noituuden kauhuja ja demonihahmoja kuvattiin rujon ja groteskin, hybrihahmoja ja perversioita esittävän ja abjektisia yksityiskohtia kaihtamattoman tyylin kautta. Monissa taiteen historian yleisesityksissä tämänkaltainen kuvasto liite-

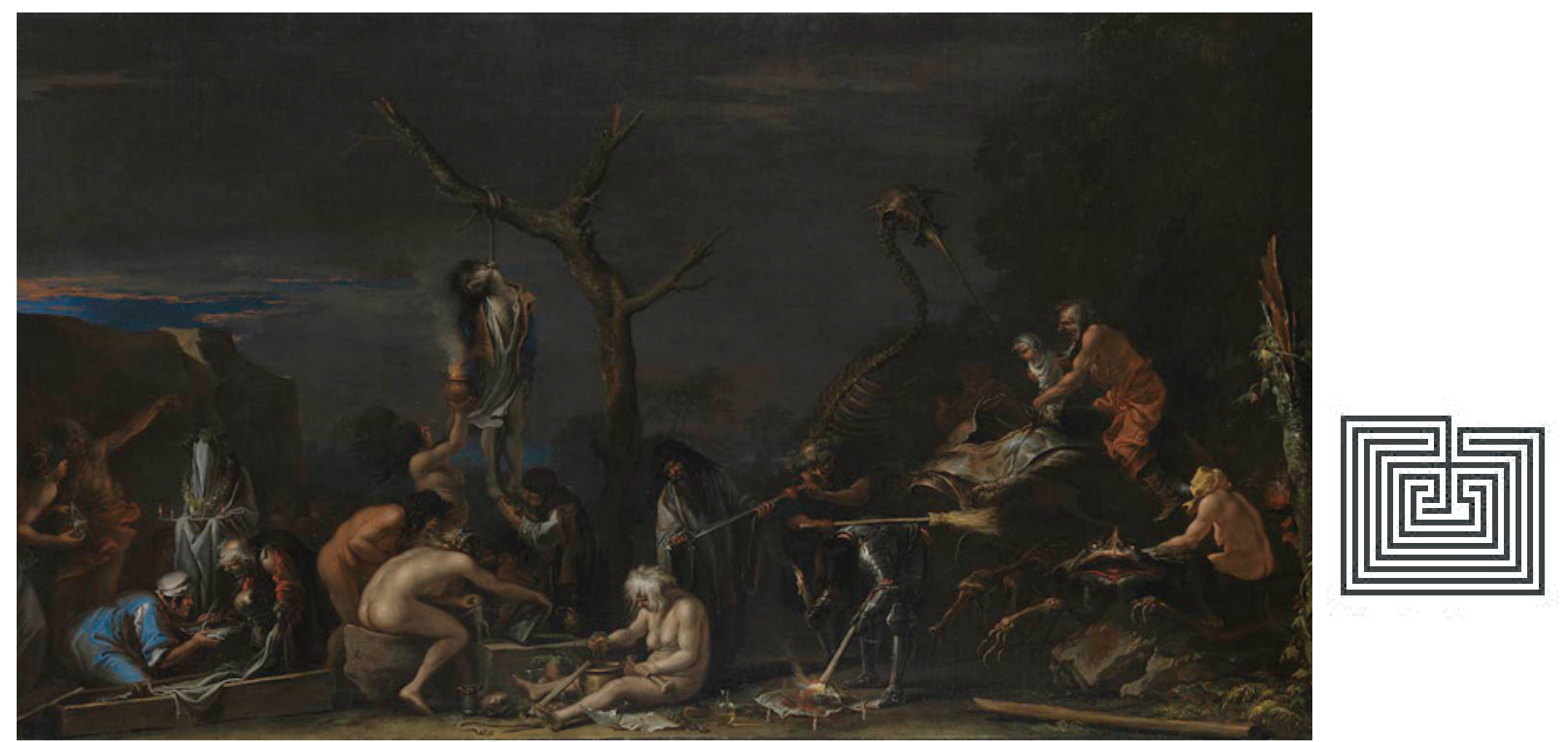

Kuva 2. Salvator Rosa, Witches at their Incantations, n. 1646. Öljyväri kankaalle, $72 \times 132 \mathrm{~cm}$. National Gallery, Lontoo. Kuva: National Gallery.

tään yksipuolisesti Düreriin ja Hieronymus Boschiin, mutta Spellboundin esillepano muistutti, että kyse oli laajasta ja pitkästä kuvaperinteestä, jonka juuret ulottuvat syvälle 1400-luvun puolelle.

Kokonaisuudessaan näyttelykonsepti oli mitä toimivin. Vaikka näyttelysalien hämyisää valaistusta ja tummaa laskostusta voi pitää itsestään selvänä valintana, oli se myös luonteva ja tunnelmallinen ratkaisu. Sopivassa taustahämärässä pienet ja hauraat näyttelyesineet pääsivät loistamaan ja avaamaan yksityiskohtansa. Pienestä mittakaavasta huolimatta kiehtovan esineistön ja valaisevien esittelyjen parissa vierähtäisi helposti parikin tuntia, ja näyttelyyn tutustumista voikin suositella lämpimästi kaikille joiden tie vie ennen Loppiaista Oxfordiin. Eri- 
tyismaininnan ansaitsee riittoisa ja rikkaasti kuvitettu, mm. Sophie Pagen ja Malcolm Gaskillin kirjoittama näyttelyjulkaisu, joka varmasti toimii - kuten itse näyttelykin erinomaisena johdatuksena magian ja taikauskon historiaan kenelle hyvänsä.

\section{Viitteet}

1 Sananmukaisesti liukuva logiikka, jolla Warburg ja Gombrich viittasivat magian taustalla oleviin irrationaaliksi nähtyihin ajattelun muotoihin, kuten taipumukseen olettaa syy-seuraussuhteita pelkästään formaalin samankal-taisuuden perusteella.

FT Lauri Ockenström tutkii ja opettaa taidehistoriaa Jyväskylän yliopistossa. Tutkimuksissaan hän on keskittynyt renessanssin uusplatonismin, magian ja esoteerisen symboliikan historiaan. Tällä hetkellä Ockenström toimii Suomen Akatemian rahoittamana tutkijatohtorina ja tutkii projektissaan planeettajumalten ikonografiaa keskiaikaisissa magian manuaaleissa. 